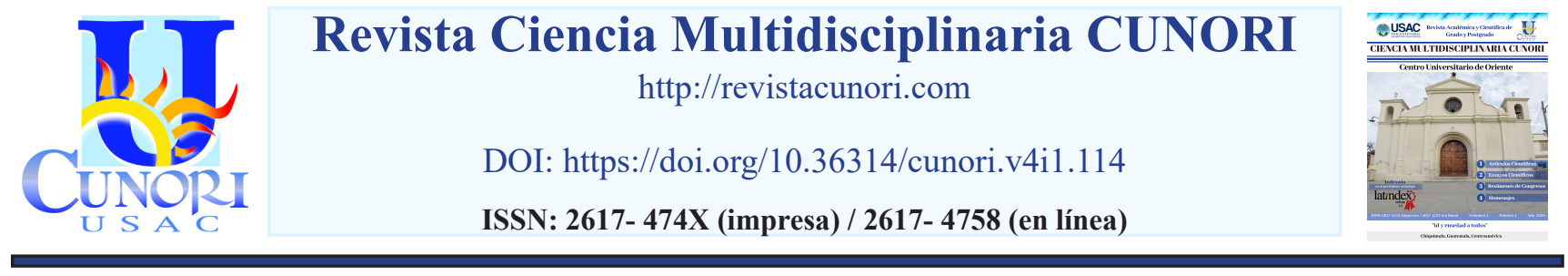

Como citar el artículo

Guancín, A. (2020). Revista Ciencia Multidisciplinaria recibe credenciales de indexación. Revista Ciencia Multidisciplinaria CUNORI, 4(1), 67-69. DOI: https://doi.org/10.36314/cunori.v4i1.114

\title{
Revista Ciencia Multidisciplinaria recibe credenciales de indexación
}

\section{Multidisciplinary Science Magazine receives indexing credentials}

\author{
Anibal Aroldo Guancín* \\ Centro Universitario de Oriente (CUNORI, Universidad de San Carlos de Guatemala \\ Recibido: 03 de noviembre de 2019 / Revisión: 10 de enero de 2020 / Aceptado: 20 de febrero de 2020 \\ Disponible en internet el 29 de mayo de 2020 \\ *Autor para correspondencia. \\ Correo electrónico: aroldoguancin@gmail.com
}

Resumen

\begin{abstract}
E n el Auditorio "Lic. Carlos Centeno" frente a investigadores, docentes, coordinadores de carreras y estudiantes, se llevó a cabo en acto especial la entrega de credenciales al Centro Universitario de Oriente -CUNORI-, por la Indexación de la Revista Ciencia Multidisciplinaria CUNORI, evento realizado por representantes del Centro de Acopio Latindex-Guatemala y la Universidad de San Carlos de Guatemala. Revista Indexada en el catálogo 2.0 del Sistema Regional de Información en Línea para Revistas Científicas de América Latina, el Caribe, España y Portugal, la cual cumple las características de calidad de Latindex. Esta acreditación la convierte en la primera y única revista de la Universidad de San Carlos de Guatemala, en indexar en el catálogo superior 2.0. La mesa principal estuvo dirigida por el Ing. Edwin Filiberto Coy Cordón, Director de CUNORI, el MS.c. Mario Roberto Díaz, Director de Postgrados, el MS.c. Nery Waldemar Galdámez Cabrera, Coordinador del Instituto de Investigación, la Licda. Claudia León, representante del Centro de Acopio de Latindex Guatemala, la Dra. Claudia Esmeralda Villela, Editora de la Revista Ciencia Multidisciplinaria CUNORI y la Licda. Rossana Chauw, encargada de Biblioteca. La Dra. Claudia Esmeralda Villela, destacó la colaboración del Dr. Gesly Aníbal Bonilla, invitado especial al acto, por su desinteresada colaboración para orientar el proceso de creación de la revista. (CUNORI, 2020).
\end{abstract}

Palabras clave: revista científica, indexación, latindex, acreditación

$\underline{\text { Abstract }}$

Tn the Auditorium "Lic. Carlos Centeno "in front of researchers, teachers, career coordinators and students, the presentation of credentials to the Oriente University Center -CUNORI- was carried out in a special act, by the Indexing of the CUNORI Multidisciplinary Science Magazine, an event carried out by representatives of the Latindex-Guatemala Collection Center and the University of San Carlos de Guatemala. Journal Indexed in catalog 2.0 of the Regional Online Information System for Scientific Journals in Latin America, the Caribbean, Spain and Portugal, which meets the quality characteristics of Latindex. This accreditation makes it the first and only journal of the Universidad de San Carlos de Guatemala, to index in the superior catalog 2.0. The main table was chaired by Ing. Edwin Filiberto Coy Cordón, Director of CUNORI, the MS.c. Mario Roberto Díaz, Postgraduate Director, MS.c. Nery Waldemar Galdámez Cabrera, Coordinator of the Research Institute, Licda. Claudia León, representative of the Latindex Guatemala Collection Center, Dr. Claudia Esmeralda Villela, Editor of the CUNORI Multidisciplinary Science Magazine and Lic. Rossana Chauw, Library Manager. Dr. Claudia Esmeralda Villela, highlighted the collaboration of Dr. Gesly Aníbal Bonilla, special guest at the event, for his disinterested collaboration to guide the process of creating the magazine. 
Keywords: scientific journal, indexing, latindex, accreditationde

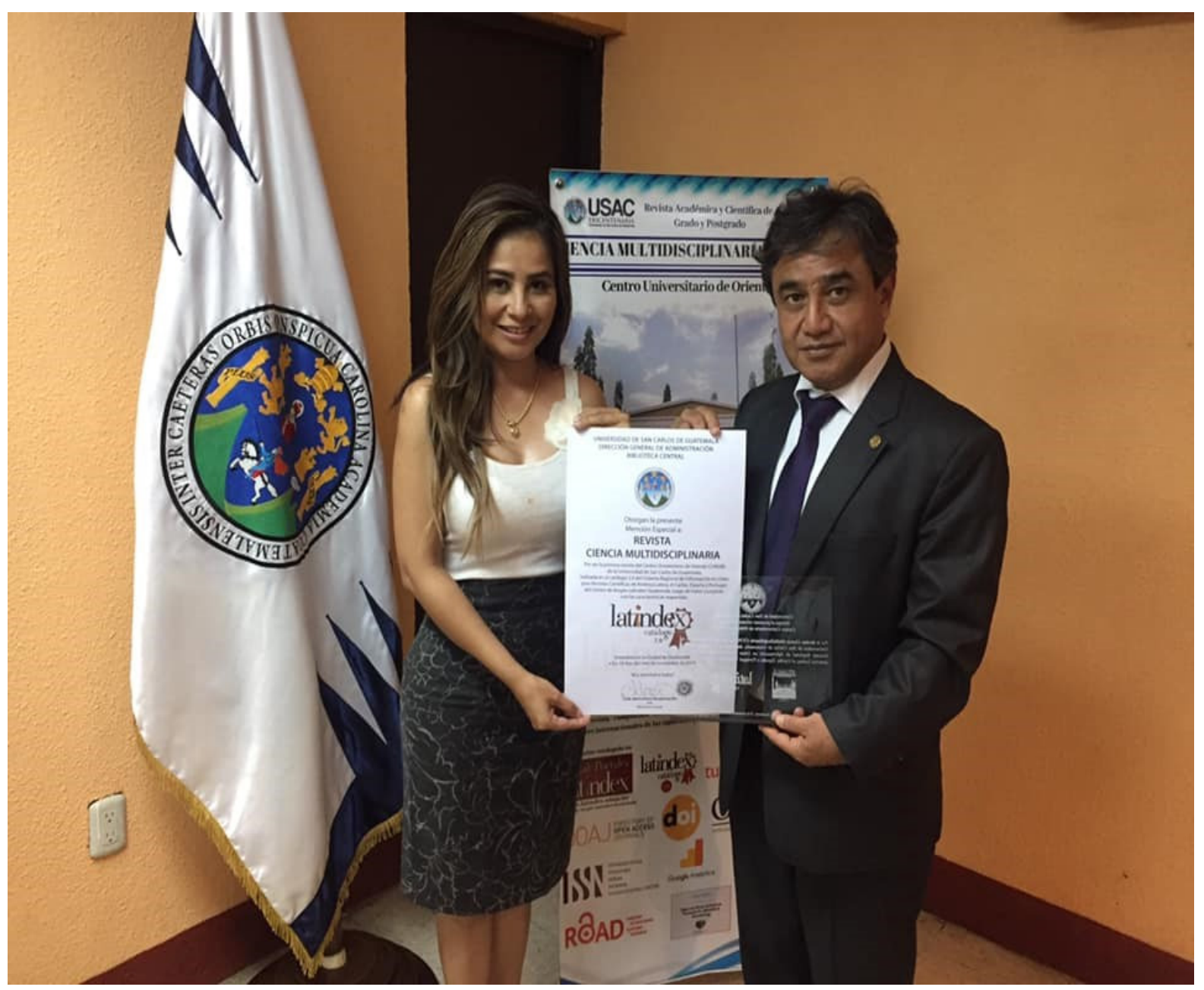

Figura No. 1 Licda. Claudia León del Centro de Acopio entregó las credenciales de Latindex al Director del Centro Universitario de Oriente -CUNORI Ing. Edwin Filiberto Coy Cordón.

\section{Sobre el autor}

\section{Anibal Aroldo Guancín}

Periodista. Licenciado en Ciencias de la Comunicación, Profesor Titular I, docente de los cursos Periodismo Radiofónico y Semiología del Mensaje Persuasivo en la Carrera de Ciencias de la Comunicación del Centro Universitario de Oriente, miembro de la comisión de Evaluación Privada de Periodista Profesional y miembro de la Cámara de Locutores Profesionales de Guatemala. 


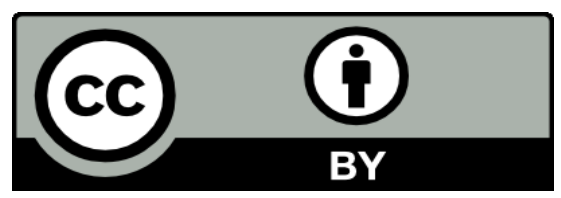

Este texto está protegido por una licencia CreativeCommons 4.0.

Usted es libre para compartir, copiar y redistribuir el material en cualquier medio o formato y adaptar el documento, remezclar, transformar y crear a partir del material para cualquier propósito, incluso comercialmente, siempre que cumpla la condición de atribución: usted debe reconocer el crédito de una obra de manera adecuada, proporcionar un enlace a la licencia, e indicar si se han realizado cambios. Puede hacerlo en cualquier forma razonable, pero no de forma tal que sugiera que tiene el apoyo del licenciante o lo recibe por el uso que hace. 